J. Y.YANG ${ }^{1}$, G. YANG ${ }^{2,3}$, J. REN ${ }^{4}$, J. ZHAO ${ }^{2}$, and $\mathrm{Sh} \mathrm{LI}^{2}$

\title{
CAFFEINE SUPPRESSES GABA RECEPTOR-MEDIATED CURRENT IN RAT PRIMARY SENSORY NEURONS VIA INHIBITION OF INTRACELLULAR PHOSPHODIESTERASE
}

\author{
Received December 30, 2013
}

In acutely isolated rat primary sensory neurons, the effects of caffeine on GABA receptormediated current $\left(I_{\mathrm{GABA}}\right)$ were investigated using a whole-cell patch clamp technique. We found that applications of GABA $(10-1000 \mu \mathrm{M})$ induced inward currents in a concentration-dependent manner; the currents manifested obvious desensitization. Pretreatment with caffeine (0.01$100 \mu \mathrm{M}$ ) suppressed $I_{\mathrm{GABA}}$ in a noncompetitive manner; caffeine shifted the concentration response curve for GABA downwards compared to the control. Theophylline showed a similar and stronger inhibitory effect on $I_{\mathrm{GABA}}$. Isolated application of $1 \mu \mathrm{M}$ diazepam enhanced $I_{\mathrm{GABA}}$, while pretreatment with $10 \mu \mathrm{M}$ caffeine and $1 \mu \mathrm{M}$ diazepam suppressed this current. Intracellular application of the protein kinase A inhibitor H-8 dramatically weakened the inhibitory effect of caffeine on $I_{\mathrm{GABA}}$. Because primary afferent depolarization is related to $\mathrm{GABA}_{\mathrm{A}}$ receptors, our results suggest that caffeine might antagonize presynaptic inhibitory effects of primary afferents, probably via inhibition of intracellular phosphodiesterase.

Keywords: GABA receptor-mesiated current, primary sensory (DRG) neurons, wholecell patch clamp, caffeine, phosphodiesterase.

\section{INTRODUCTION}

Caffeine and theophylline are methylxanthine alkaloids. These drugs exert a number of pharmacological effects; they antagonize asthma, relax smooth muscles, excite the CNS and cardiac muscle, influence diuresis, etc. [1-3]. The mechanisms underlying these effects, according to the data available, may include antagonism with respect to the adenosine receptors [4-6], inhibition of phosphodiesterase $[7,8]$, acceleration of the release of intracellular calcium $[9,10]$, competitive action on benzodiazepine receptors, and influence on GABA receptor-mediated effects $[3,11,12]$. GABA is one of the primary inhibitory neurotransmitters in the spinal cord and brain; it induces depolarization of terminals of primary afferent fibers and, due to this, reduces the release of an excitatory transmitter from primary

\footnotetext{
${ }^{1}$ Department of Urology Dalian Friendship Hospital, Dalian, China.

${ }^{2}$ Department of Physiology.

${ }^{3}$ Department of Clinical Medicine, Anesthesiology Major, Dalian Medical University, Dalian, China.

${ }^{4}$ Department of Anesthesiology, Jinan Central Hospital, Jinan, China.

Correspondence should be addressed to

Sh.Li (e-mail: lishao89@hotmail.com),

J. Zhao (e-mail: zhaoj@dlmedu.edu.cn),

J. Y. Yang (e-mail : yangjinyi90@hotmail.com).
}

afferent neurons providing, in such a way presynaptic inhibition.

Our study was aimed at an investigation of the effects of caffeine on $\mathrm{GABA}_{\mathrm{A}}$ receptor-mediated responses in acutely isolated rat primary sensory neurons (dorsal root ganglion neurons, DRG neurons). We believe that our findings may throw light on the understanding of the mechanism underlying modulation of the activity of primary afferents.

\section{METHODS}

Isolation of DRG Neurons. Two- to three-weekold Sprague-Dawley rats of both sexes $(n=18)$ were obtained from the Faculty of Laboratory Animal Science, Dalian Medical University. The rats were anaesthetized with ether and then decapitated. The thoracic and lumbar segments of the vertebral column were dissected and longitudinally divided into two halves along the median line on both dorsal and ventral sides. Dorsal root ganglions (DRGs), together with the dorsal and ventral roots and attached spinal nerves, were taken out and transferred immediately into Dulbecco's modified Eagle's medium (DMEM) 
at $\mathrm{pH}$ 7.4. After the removal of attached nerves and surrounding connective tissues, the DRGs were minced with fine spring scissors, and ganglion fragments were placed in a flask containing $5 \mathrm{ml}$ DMEM with trypsin (type III), collagenase (type I), and collagenase (type II; $0.5 \mathrm{mg} / \mathrm{ml}$ each) added, and incubated at $35^{\circ} \mathrm{C}$ for 30-35 min in a shaking water bath. Soybean trypsin inhibitor (type II-s, $1.25 \mathrm{mg} / \mathrm{ml}$ ) was then added to stop trypsin digestion. Dissociated neurons were placed into a $35-\mathrm{mm}$ Petri dish and kept for at least $30 \mathrm{~min}$ before electrophysiological recording. The somata of neurons selected for recording were 15-45 $\mu \mathrm{m}$ in diameter. All reagents mentioned above were from Sigma (USA)

Electrophysiological Recordings. Whole-cell patch clamp recording was carried out using an EPC10 amplifier (HEKA Electronik, Germany). Pulse and PulseFit 8.6 software programs were used for data acquisition and analysis. Electrodes were pulled from borosilicate glass capillaries on a micropipette puller (Narrishige, PP 830, Japan); their resistance was 3-6 $\mathrm{M} \Omega$ when filled with an internal solution containing $(\mathrm{mM}): \mathrm{KCl}, 140 ; \mathrm{MgCl}_{2}, 2.5$; Hepes, 10; EGTA, 11; ATP, 5 (osmolarity adjusted to 320 mosmol/1 with sucrose; $\mathrm{pH}$ adjusted to 7.2 with $\mathrm{KOH}$ ). Cells were bathed in an external solution containing $(\mathrm{mM}): \mathrm{NaCl}$, 150 ; $\mathrm{KCl}, 5 ; \mathrm{CaCl}_{2}, 2.5 ; \mathrm{MgCl}_{2}, 2$; Hepes, 10; D-glucose, 10 (osmolarity adjusted to $320 \mathrm{mosmol} / 1$ with sucrose; $\mathrm{pH}$ adjusted to 7.4 with $\mathrm{NaOH}$ ). A small patch of the membrane underneath the tip of the pipette was aspirated to form a gigaohm seal (1-10 G $\Omega$ ), and then a more subatmospheric pressure was applied to rupture it, thus establishing a whole-cell configuration. Currents were filtered at $1 \mathrm{kHz}$ and digitized at $10^{4} \mathrm{sec}^{-1}$. Adjustment of capacitance compensation and series resistance compensation was done before recording the membrane currents. The leak current was digitally subtracted. Experiments were carried out with the membrane potential held at $-60 \mathrm{mV}$. All recordings were performed at room temperature $\left(22-24^{\circ} \mathrm{C}\right)$.

Intracellular Dialysis using the Repatch Technique. For the repatch experiment, the first patch was used as the control, with the pipette filled with the normal internal solution. After the current had been recorded, the pipette was discarded. On the same neuron, the second patch was performed using another pipette that was filled with the internal solution containing H-8 (N-[2-(methylamino)ethyl]5 -isoquinoline sulfonamide $\cdot 2 \mathrm{HCl})$, an inhibitor of protein kinase A. After $30 \mathrm{~min}$, the membrane current was recorded again and compared with the control one.
Drug Application. Drugs used in the experiments, caffeine, GABA, theophylline, diazepam, and H-8 (all from Sigma, USA) were dissolved in external or internal solutions just before use. All drugs except for H-8 were dissolved in the external solution and applied by gravity flow from a linear array of fused silica tubules (external and internal diameters 500 and $200 \mu \mathrm{m}$, respectively) connected to a series of independent reservoirs. The distance from the tubule mouth to the cell examined was about $100 \mu \mathrm{m}$. Application of each drug was driven by gravity and controlled by the corresponding valve, and rapid solution exchange could be achieved within about $100 \mathrm{msec}$ by shifting the tubes horizontally with a micromanipulator. Cells were constantly bathed between drug applications in the normal external solution flowing from one tube connected to a larger reservoir. In the experiments where H-8 was applied intracellularly, it was dissolved in the internal solution before use. The interval between GABA applications was at least $4 \mathrm{~min}$, in order to avoid desensitization.

Statistics. Numerical data were statistically compared using the Student's t-test or ANOVA. Statistical analysis of the concentration-response data was performed using a nonlinear curve-fitting program, ALLFIT. The values for currents are expressed as means \pm s.e.m. Differences with $P<0.05$ were considered significant.

\section{RESULTS}

Freshly isolated neurons from the rat DRGs had a round or oval shape with a residue of the stem process, which was cut off by enzymatic and mechanical treatment. Experiments were carried out on 146 freshly isolated DRG neurons, the diameters of which varied from 15 to $45 \mu \mathrm{m}$.

GABA Receptor-Mediated Current. In the majority of the neurons examined (138/146, 94.5\%), GABA $(10-1000 \mu \mathrm{M})$ induced inward currents in a dose-dependent manner (Fig. 1A). This GABA receptor-mediated current $\left(I_{\mathrm{GABA}}, 300 \mu \mathrm{M}\right)$ could be mimicked by $300 \mu \mathrm{M}$ muscimol (B) and blocked by $300 \mu \mathrm{M}$ bicuculline, a selective antagonist of $\mathrm{GABA}_{\mathrm{A}}$ receptors, which indicated that this current was mediated by the $\mathrm{GABA}_{\mathrm{A}}$ receptors (C). This kind of current exhibited an apparent desensitization, especially at high concentrations. When GABA was applied repetitively for $20 \mathrm{sec}$ with 4-min-long intervals, $I_{\mathrm{GABA}}$ was stable for at least $90 \mathrm{~min}$, and the 


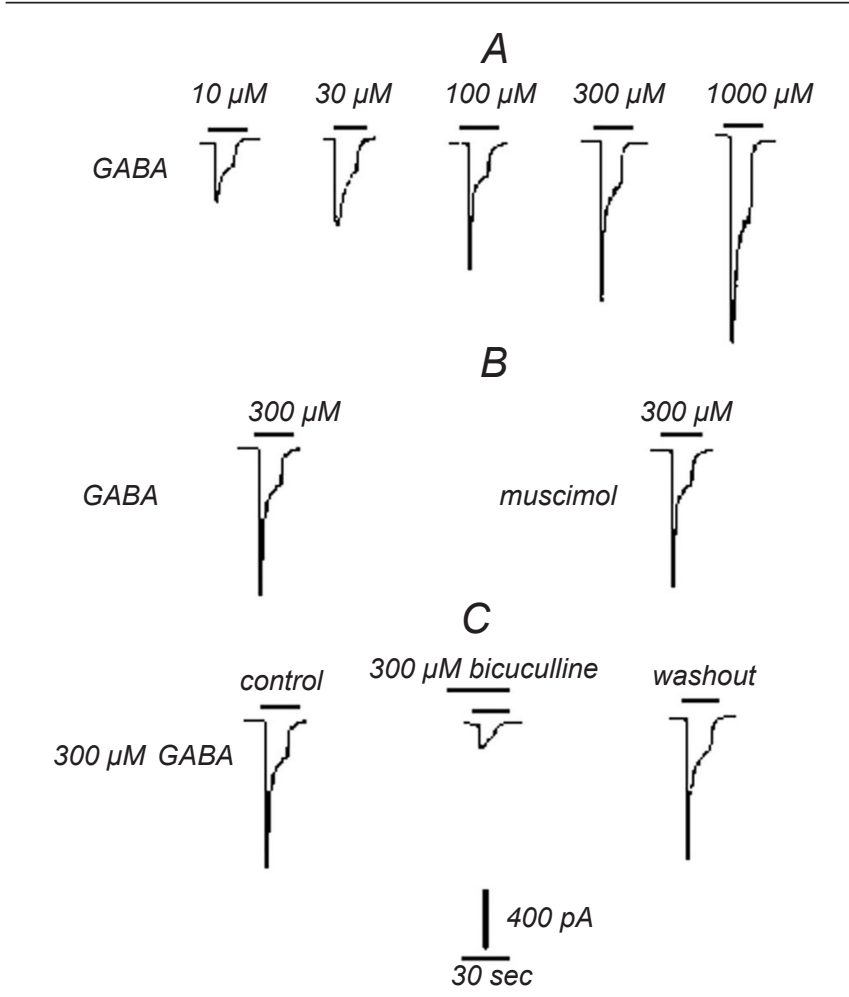

F i g. 1. GABA receptor-mediated currents $\left(I_{\mathrm{GABA}}\right)$ in DRG neurons and their inhibition by bicuculline. A) Traces of $I_{\mathrm{GAB}}$ induced by applications of GABA in different concentrations $(10-1000 \mu \mathrm{M})$. B) Inward currents evoked by separate applications of $300 \mu \mathrm{M}$ GABA and $300 \mu \mathrm{M}$ muscimol. C) Inward current evoked by $300 \mu \mathrm{M}$ GABA, and blocking of this current by the $\mathrm{GABA}_{\mathrm{A}}$ receptor antagonist bicuculline $(300 \mu \mathrm{M})$.

P и с. 1. Струми, опосередковані рецепторами ГАМК, у нейронах дорсального ганглію та гальмування цих струмів бікукуліном.

variation of its amplitude did not exceed $7.0 \%$ (data not shown). Thus, we used this pattern of GABA applications in the following experiments.

Modulatory Effects of Caffeine on GABAActivated Current in Rat DRG Neurons. When caffeine (0.01-100 $\mu \mathrm{M})$ was applied for 1 min prior to application of GABA $(100 \mu \mathrm{M})$, attenuation of $I_{\mathrm{GABA}}$ was observed. The inhibitory effect of caffeine depended on the concentration of the latter. The current activated by $100 \mu \mathrm{M}$ GABA was suppressed by $13.2 \pm 4.8 \%(n=9), 20.2 \pm 3.1 \%(n=9), 38.9 \pm$ $\pm 6.1 \%(n=9), 43.6 \pm 5.5 \%(n=9)$, and $44.3 \pm 6.1 \%$ $(n=9)$ when $0.01,0.1,1,10$, and $100 \mu \mathrm{M}$ caffeine were pre-applied, respectively. The concentrationresponse curve of caffeine inhibition of $I_{\mathrm{GABA}}$ was S-shaped, and the $\mathrm{IC}_{50}$ value was $10 \mu \mathrm{M}$ (Fig. 2). $I_{\mathrm{GABA}}$ recovered quickly after caffeine-induced inhibition; complete recovery was observed in about 4 min (not shown). Therefore, a 4-min-long interval between
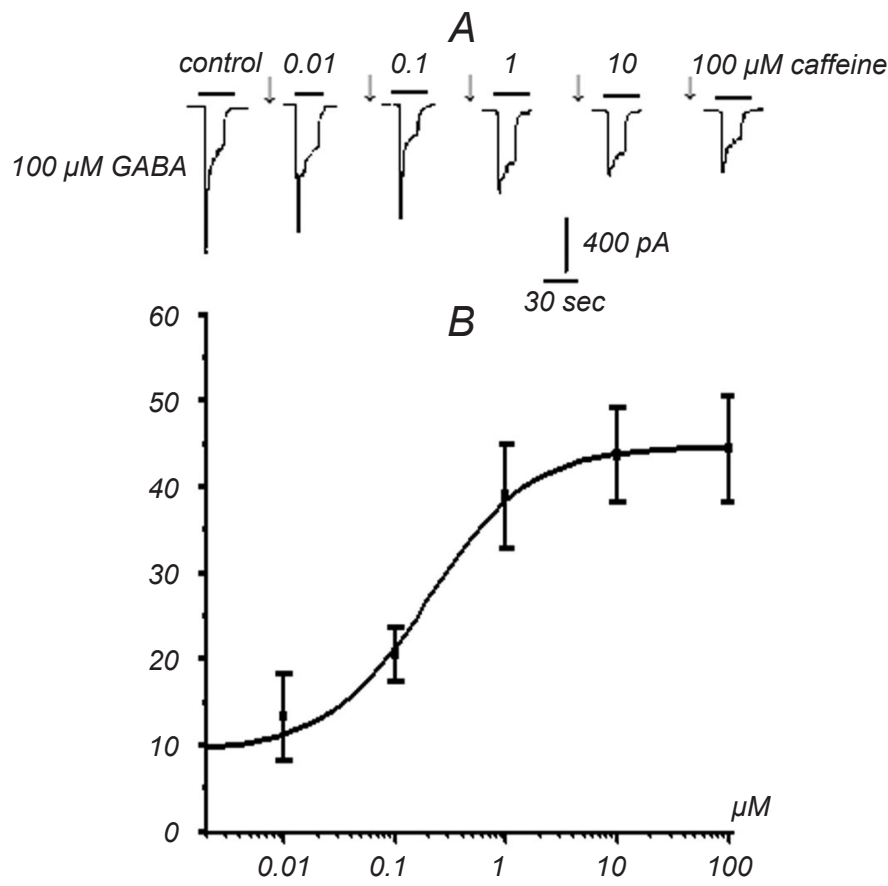

F i g. 2. Inhibition of GABA receptor-mediated current ( $I_{\mathrm{GABA}}$, $100 \mu \mathrm{M}$ GABA) by 1 -min-long pretreatment with caffeine. A) Suppression of $I_{\mathrm{GABA}}$ induced by caffeine in different concentrations $(0.01-100 \mu \mathrm{M})$ in the same DRG neuron. B) Dose-dependence curve of inhibition of $I_{\mathrm{GABA}}(100 \mu \mathrm{M})$ by caffeine $(0.01-100 \mu \mathrm{M})$.

P и с. 2. Пригнічення струму, опосередкованого рецепторами ГАМК - $I_{\text {GABA }}(100$ мКМ ГАМК), після однохвилинної попередньої обробки кофеїном.

caffeine applications was used in the subsequent study.

Concentration-Response Relationship for Caffeine Inhibition of GABA Receptor-Mediated Current. Figure 3 shows the concentration-response curves for $I_{\mathrm{GABA}}$ in the absence (1) and presence (2) of $100 \mu \mathrm{M}$ caffeine $(n=9)$. All responses were normalized with respect to the peak current induced by $1000 \mu \mathrm{M}$ GABA alone. Caffeine $(10 \mu \mathrm{M})$ shifted the concentration-response curve of $I_{\mathrm{GABA}}$ downward markedly, and the maximal $I_{\mathrm{GABA}}$ decreased to $57 \%$ of its control. The EC50 values for both curves were very close $(28$ vs $30 \mu \mathrm{M})$ and showed no statistical difference.

Inhibitory Effect of Theophylline on GABA Receptor-Mediated Current. The modulatory effects of $10 \mu \mathrm{M}$ caffeine and $10 \mu \mathrm{M}$ theophylline on GABA receptor-mediated current in the same DRG neurons were compared. Both these drugs induced inhibition of $\mathrm{I}_{\mathrm{GABA}}$, and the mean inhibition rates were $24.5 \pm$ $\pm 8.7 \%(n=9)$ and $41.1 \pm 11.0 \%(n=9)$, respectively (data for each group are from the same DRG neurons). Thus, theophylline exerted a noticeably stronger 


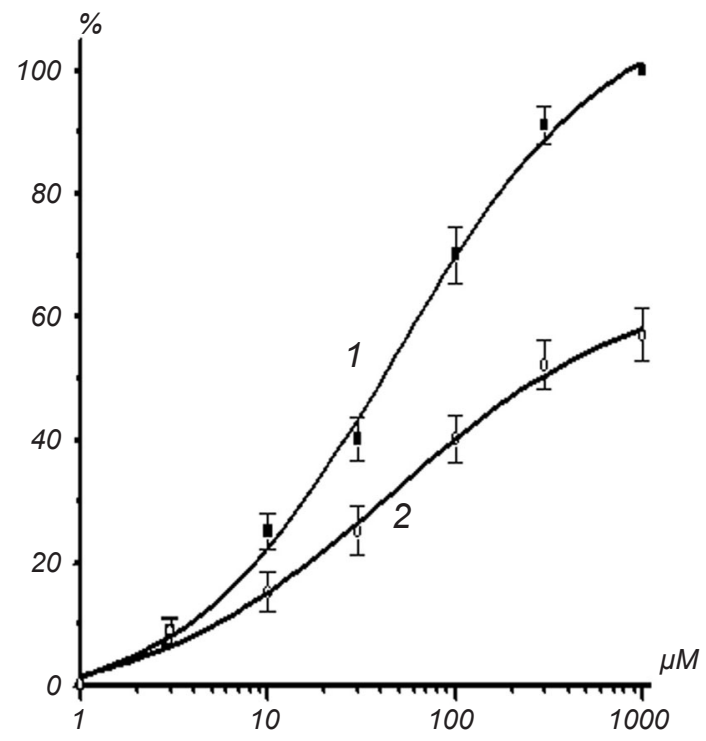

F i g. 3. Concentration - response graphs for $I_{\mathrm{GABA}}$ without pretreatment with caffeine (1) and with such pretreatment $(100 \mu \mathrm{M}, 2)$. Each point represents the mean \pm s.e.m. for 8-10 DRG neurons. All GABA-induced currents were normalized with respect to the response induced by $1.0 \mathrm{mM}$ GABA applied alone.

Р и с. 3. Графіки «концентрація-відповідь» для струму, опосередкованого рецепторами ГАМК $\left(I_{\mathrm{GABA}}\right)$, без попередньої обробки кофеїном (1) та після неї (100 мкМ; 2).

inhibitory effect on $\mathrm{I}_{\mathrm{GABA}}$ than caffeine at the same concentration ( $\mathrm{P}<0.01$, Fig. 4).

Modulation by Diazepam of GABA ReceptorMediated Current. In the same DRG neurons, $\mathrm{I}_{\mathrm{GABA}}(100 \mu \mathrm{M})$ was enhanced by $19.3 \pm 2.2 \%$ with pretreatment by diazepam $(10 \mu \mathrm{M}, 60 \mathrm{sec} ; \mathrm{n}=9)$, whereas simultaneous application of diazepam and caffeine decreased $\mathrm{I}_{\mathrm{GABA}}$ by $26.0 \pm 7.5 \%(\mathrm{n}=9)$ (Fig. $5)$.

Dependence of Caffeine-Induced Inhibition of $I_{G A B A}$ on the Pretreatment Time. As is shown in Fig. 6, caffeine did not suppress GABA receptormediated currents when this agent was applied to the DRG neurons simultaneously with GABA (i.e., with no pretreatment). However, when pre-application of caffeine lasted at least $20 \mathrm{sec}$, the inhibition of $\mathrm{I}_{\mathrm{GABA}}$ by this drug emerged clearly. This suggests that inhibition of $\mathrm{I}_{\mathrm{GABA}}$ by caffeine is a time-dependent process, and, thus, some intracellular signal transduction pathway may be involved. Caffeine-induced inhibition on $\mathrm{I}_{\mathrm{GABA}}$ increased gradually when the pretreatment duration was extended from 20 to $80 \mathrm{sec}$, and it reached a maximum value at the latter duration (Fig. 6).

Analysis of the Intracellular Signal Transduction Route Involved in Suppression of $I_{G A B A}$ by Caffeine. Considering the manner in which caffeine shifted the
$A$
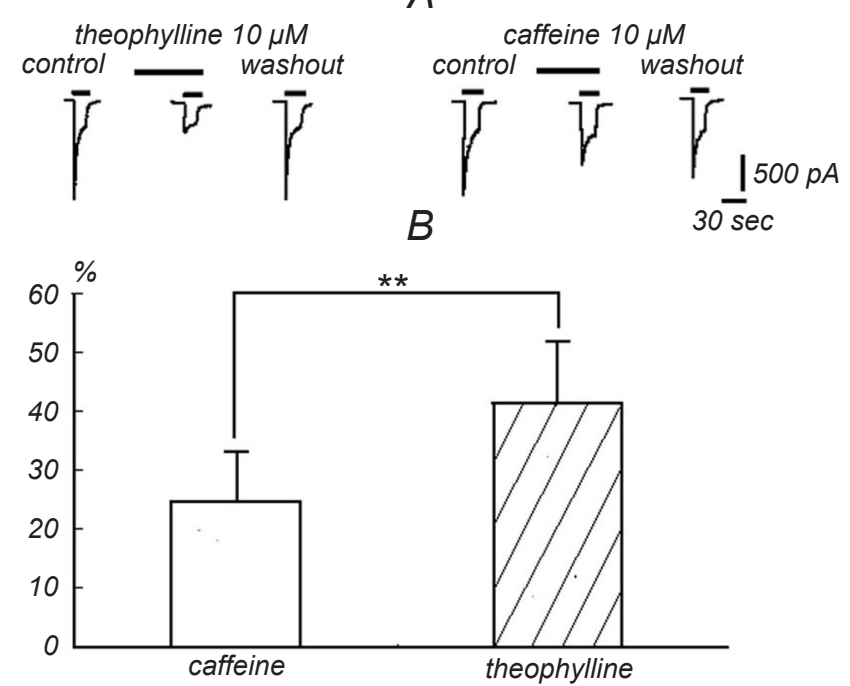

F i g. 4. Comparison of the modulatory effects of caffeine and theophylline on GABA receptor-mediated currents $\left(I_{\mathrm{GABA}}\right)$. A) Current traces showing the inhibitory effects of theophylline and caffeine in the same concentrations on $I_{\mathrm{GABA}}$ (traces for each group are from the same DRG neuron). B) Diagram of the mean intensities of inhibition of $I_{\mathrm{GABA}}$ exerted by caffeine $(n=9)$ and theophylline ( $n=9$; comparisons were performed in the same DRG neurons).

Р и с. 4. Порівняння модуляторних впливів кофеїну та теофіліну на струми, опосередковані рецепторами ГАМК $\left(I_{\mathrm{GABA}}\right)$.

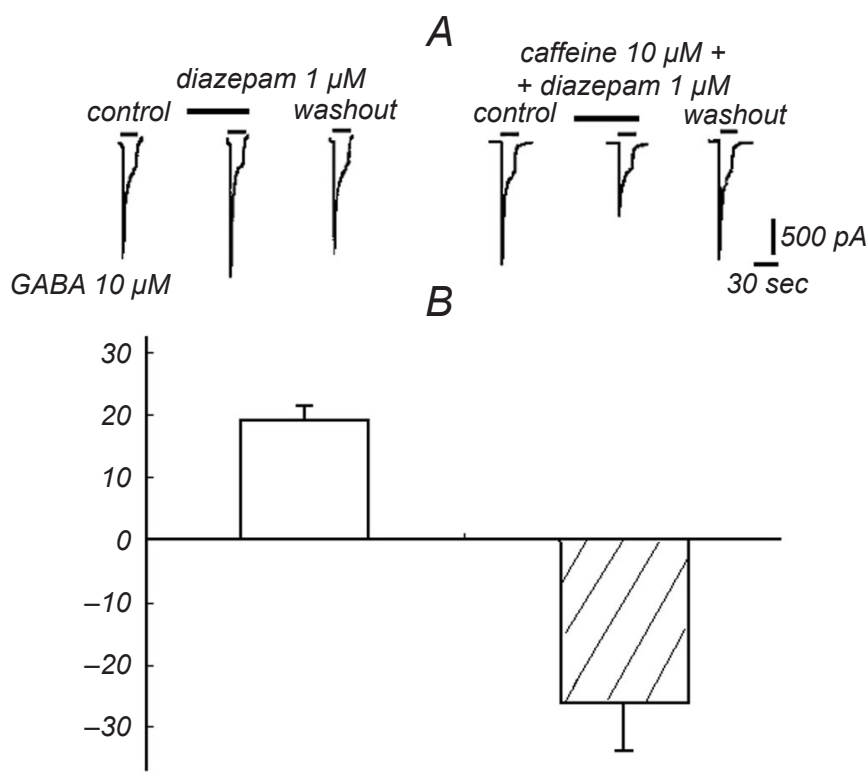

F i g. 5. Modulatory effects of caffeine and diazepam on GABA receptor-mediated current $\left(I_{\mathrm{GABA}}\right)$. A) Potentiation of $I_{\mathrm{GABA}}$ by isolated action of diazepam and inhibition of this current by simultaneous diazepam and caffeine preapplication (traces are from the same DRG neuron). B) Diagram of the normalized changes in the $I_{\mathrm{GABA}}$ amplitude induced by isolated action of diazepam and simultaneous preapplication of diazepam and caffeine $(n=9)$.

Р и с. 5. Модуляторні впливи кофеїну та діазепаму на струми, опосередковані рецепторами ГАМК. 


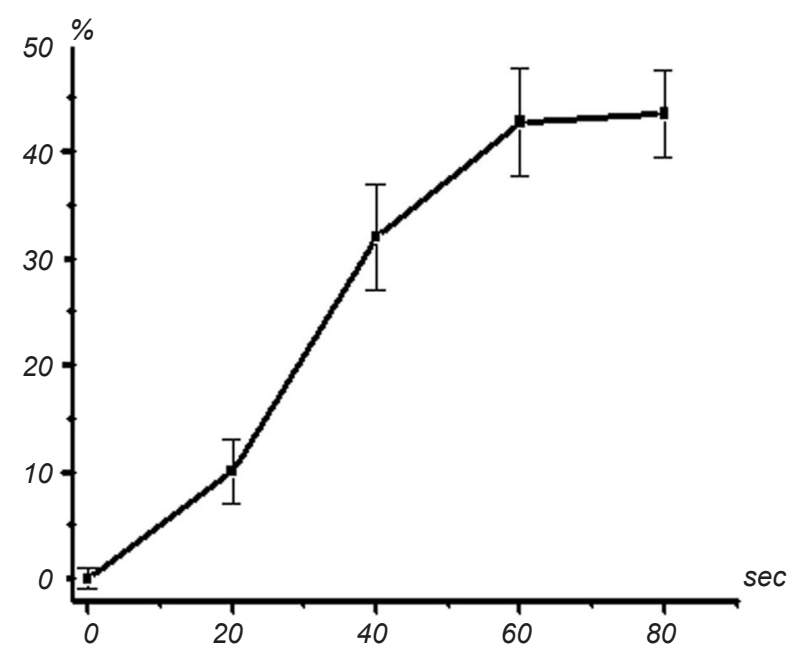

F i g. 6. Dependence of inhibition of GABA receptor-mediated current $I_{\mathrm{GABA}}(100 \mu \mathrm{M})$ on the duration of pre-application of caffeine $(10 \mu \mathrm{M})$. Each point represents the mean \pm s.e.m. of $6-9$ neurons.

P и с. 6. Залежність пригнічення струму, опосередкованого рецепторами ГАМК (100 мкМ ГАМК), від тривалості попередньої аплікації 10 мкМ кофеїну.

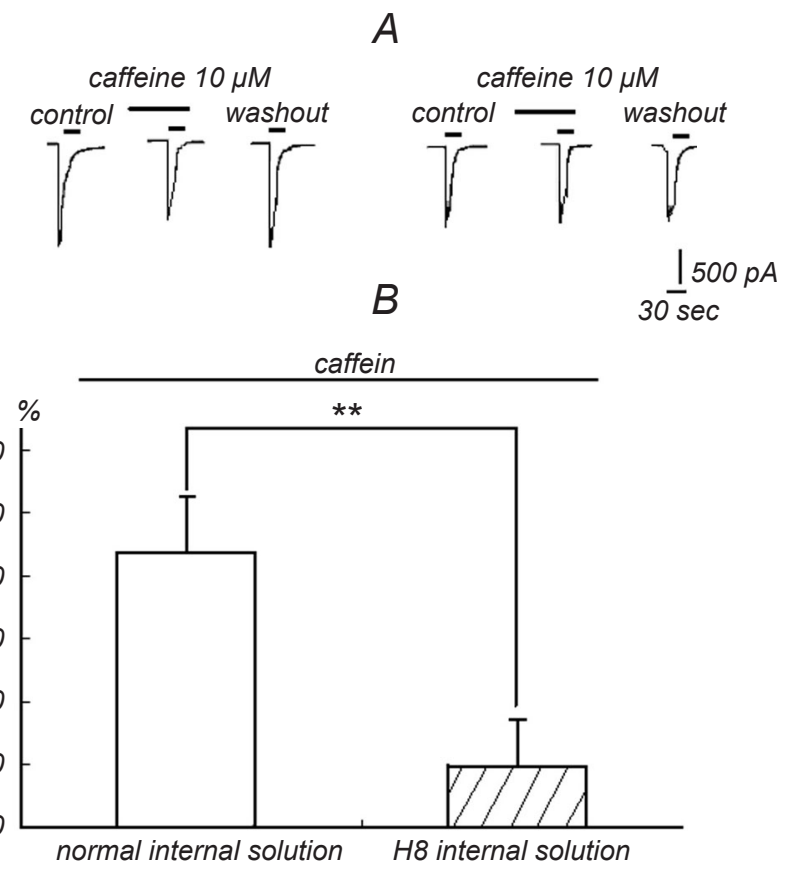

F i g. 7. Analysis of the intracellular signal transduction route involved in suppression of $I_{\mathrm{GABA}}$ by caffeine A) Effect of intracellular dialysis with $\mathrm{H}-8(50 \mu \mathrm{M})$-containing solution abolishing the inhibitory effect of caffeine $(10 \mu \mathrm{M})$ on $I_{\mathrm{GABA}}$. B) Diagram comparing the inhibitory effect of caffeine $(10 \mu \mathrm{M})$ with the normal internal solution and the effect after repatch with intracellular dialysis by H-8-containing solution $(n=7, P<0.001)$

Р и с. 7. Аналіз шляху передачі внутрішньоклітинних сигналів, який залучений в пригнічення кофеїном струму, опосередкованого рецепторами ГАМК $\left(I_{\mathrm{GABA}}\right)$. concentration - response curve of $\mathrm{I}_{\mathrm{GABA}}$ downward markedly (Fig. 3), it was hypothesized that such suppression is noncompetitive and is caused by modulation of the $\mathrm{GABA}_{\mathrm{A}}$ receptor function via intracellular phosphorylation. To elucidate this question, H-8 (an inhibitor of protein kinase A) was added to the solution in the recording pipette for intracellular dialysis using the repatch technique. In the neurons treated with $50 \mu \mathrm{M} \mathrm{H}-8$, inhibition of IGABA by caffeine was abolished almost completely in 5 min $(\mathrm{P}<0.01, n=7)$ (Fig. 7A). As is seen in Fig. 7B, when the pipette was filled with the normal internal solution, caffeine-induced suppression of $\mathrm{I}_{\mathrm{GABA}}$ was $43.9 \pm 5.1 \%$, on average $(n=7)$. At the same time, suppression of $\mathrm{I}_{\mathrm{GABA}}$ induced by caffeine was dramatically weaker $30 \mathrm{~min}$ after intracellular dialysis of the cell with the H-8-containing solution $(8.5 \pm 4.5 \%, P<0.01)$. Considering that there was damage of the plasma membrane after the first patchclamping, and dialysis of the cell interior with the fluid contained in the patch pipette could modify the cell function, we also compared $\mathrm{I}_{\mathrm{GABA}}$ between the first patch-clamping group and the repatch control group using micropipettes filled with the normal internal solution. No significant difference of $\mathrm{I}_{\mathrm{GABA}}$ for two groups was found ( $n=3$, data not shown).

\section{DISCUSSION}

The mechanisms of caffeine antagonizing actions of GABA and glycine have been studied by Uneyama et al. [3] on freshly isolated rat hippocampal neurons. In our research, we confirmed the concentration-dependent inhibition exerted by caffeine $(0.01-100 \mu \mathrm{M})$ on $I_{\mathrm{GABA}}\left(100 \mu \mathrm{M} ; \mathrm{IC}_{50}=10 \mu \mathrm{M}\right)$ in rat DRG neurons. We found that this effect is stronger than that in hippocampal neurons (range of caffeine concentrations 10-10,000 $\mu \mathrm{M}, \quad \mathrm{IC}_{50}=3.6 \mathrm{mM}$ ). The difference between results of our study on DRG neurons and Uneyama's experiments on hippocampal neurons is the following. In the latter study, caffeine shifted the GABA concentration-response curve rightward and increased $\mathrm{Kd}$ without changing the maximum response. These results were interpreted in such a way that the inhibitory effect in hippocampal neurons was competitive. Intracellular application of BAPTA (a calcium ion chelator) and H-8 (a PKA inhibitor) did not affect depression of $I_{\mathrm{GABA}}$ by caffeine in the above neurons. On the contrary, our study showed that caffeine in DRG neurons shifted the GABA 
concentration - response curve downward and decreased the maximum response to $57 \%$. These results provide reasons to believe that the effect of caffeine in DRG neurons is noncompetitive with respect to the $\mathrm{GABA}_{\mathrm{A}}$ receptor- $\mathrm{Cl}^{-}$channel complex. Intracellular dialysis with $\mathrm{H}-8$ using the repatch techniques almost completely abolished caffeine-induced inhibition of $I_{\mathrm{GABA}}$.

It has been reported that phosphorylation and dephosphorylation of the $\mathrm{GABA}_{\mathrm{A}}$ receptor-chloride channel complex are involved in modulation of the GABA-evoked responses [13]. Biochemical studies have suggested that phosphorylation of the $\mathrm{GABA}_{\mathrm{A}}$ receptors by various protein kinases inhibits the function of these receptor [14]. In agreement with our results, many studies also showed that cyclic AMP-dependent protein kinase directly phosphorylates $\mathrm{GABA}_{\mathrm{A}}$ receptors and decreases GABA-activated currents in DRG and spinal cord neurons $[15,16]$. We concluded that caffeine-induced inhibition of the GABA response is mediated by the action of intracellular cAMP and $\mathrm{GABA}_{\mathrm{A}}$ receptor phosphorylation via intracellular phosphoinositides/PKA. The discrepancy between our results and Uneyama's report may be related to different specimens and remains to be further investigated.

Previous studies showed that the excitatory effect of caffeine on the nervous system is due to its antagonizing action on $\mathrm{A}_{2 \mathrm{~A}}$ receptors [17]. Recent reports, however, suggested that the caffeine intracellular pathways may be related to phosphorylation of DARPP-32 (dopamine- and cyclic AMP-regulated phosphoprotein with a molecular mass 32,000) [17-20]. As was mentioned above, the mechanisms underlying the effects of caffeine are variable. It was shown that methylxanthine alkaloids compete with caffeine in binding to benzodiazepine receptors [21]. In our study, we found that when DRG neurons were treated with diazepam prior to GABA, $I_{\mathrm{GABA}}$ was enhanced, while simultaneous application of diazepam and caffeine resulted in inhibition on $I_{\mathrm{GABA}}$ (Fig. 5). Caffeine increases the cAMP level via two routes; it antagonizes adenosine receptors $[17,22]$ and inhibits intracellular phosphodiesterase (PDE) $[7,8]$. As to the former aspect, we found that the inhibitory effect of adenosine on $I_{\mathrm{GABA}}$ in rat DRG neurons is mediated by subunit $\mathrm{A}_{1}$ adenosine receptors and not by $\mathrm{A}_{2 \mathrm{~A}}$ receptors [23]. Therefore, caffeine may antagonize $A_{1}$ receptors. In our experiments, there was no activation of the adenosine system. Thus, we can infer that the effect of caffeine in this situation may be due mainly to increase in the intracellular cAMP level via inhibition of PDE. As is known, caffeine acts directly on the endoplasmic reticulum providing release of calcium and increase in the intracellular calcium concentration. These processes may, in principle, contribute to caffeine-induced suppression of $I_{\mathrm{GABA}}[24,25]$. In our experiment, however, the effect of an increase in the intracellular calcium level could not be significant because EGTA was present in the intracellular solution.

Thus, we found in our study that caffeine inhibits functioning of $\mathrm{GABA}_{\mathrm{A}}$ receptors in rat DRG neurons. If primary afferent depolarization is related to the function of $\mathrm{GABA}_{\mathrm{A}}$ receptors, caffeine might counteract presynaptic inhibitory action on primary afferents. Inhibition of PDE is the most probable route via which caffeine exerts its influence on the GABA inhibitory system. The inhibitory effect of caffeine on $\mathrm{GABA}_{\mathrm{A}}$ receptors might be a significant aspect on the activating influence of this agent on both the CNS and the peripheral nervous system.

Acknowledgments. This work was supported by grants from the National Natural Science Foundation of China (Nos. 81371437, 81371223, and 30871006) and Research Fund for the Doctoral Program of Higher Education of China (No. 20122105110010).

All experiments were conducted in accordance with the National Institutes of Health Guide for the Care and Use of Laboratory Animals and international ethical standards. All efforts were made to minimize the number of animals used and their suffering.

The authors of this study, J. Y. Yang, G. Yang, J. Ren, J. Zhao, and Sh. Li, confirm that the research and publication of the results were not associated with any conflicts regarding commercial or financial relations, relations with organizations and/or individuals who may have been related to the study, and interrelations betveen co-authors of the article.

Дж. І. Янг

КОФЕЇН ПРИГНІЧУЄ В ПЕРВИННИХ СЕНСОРНИХ НЕЙРОНАХ ЩУРА СТРУМ, ОПОСЕРЕДКОВАНИЙ РЕЦЕПТОРАМИ ГАМК, ЗАВДЯКИ ГАЛЬМУВАННЮ ВНУТРІШНЬОКЛІТИННОЇ ФОСФОДІЕСТЕРАЗИ

\footnotetext{
1 Лікарня «Дружба», Далянь (Китай).

2 Далянський медичний університет (Китай).

${ }^{4}$ Центральна лікарня м. Джінань (Китай).
} 
Р е $з$ ю м е

Досліджували впливи кофеїну на струми, опосередковані рецепторами ГАМК $\left(I_{\mathrm{GABA}}\right)$, в гостроізольованих первинних нейронах щура; використовували методику петчклемп у конфігурації «ціла клітина». Аплікації ГАМК (10-1000 мкМ) викликали струми вхідного напрямку, амплітуда котрих була залежною від концентрації; струми демонстрували яскраво виражену десенситизацію. Попередня обробка кофеїном (0.01-100 мкМ) призводила до неконкурентного пригнічення $I_{\mathrm{GABA}}$. Вплив кофеїну зміщував вниз криву концентрація-відповідь для ГАМК порівняно 3 контролем. Теофілін демонстрував подібні й навіть сильніші гальмівні впливи на $I_{\mathrm{GABA}}$. Ізольована аплікація 1 мкМ діазепаму посилювала $I_{\mathrm{GABA}}$, тоді як попередня обробка 10 мкМ кофеїну перед дією 1 мкМ діазепаму пригнічувала цей струм. Внутрішньоклітинна аплікація Н-8 (інгібітору протеїнкінази А) дуже значно послаблювала гальмівний вплив кофеїну на $I_{\mathrm{GABA}}$. Оскільки деполяризація терміналий первинних аферентів опосередковується рецепторами ГАМК, наші результати вказують на те, що кофеїн може протистояти пресинаптичному гальмуванню первинних аферентів. Ефекти кофеїну опосередковуються гальмуванням внутрішньоклітинної фосфодіестерази.

\section{REFERENCES}

1. T. Somekawa-Kondo, K. Yamaguchi, Y. Ishitsuka, et al., "Aminophylline, administered at usual doses for rodents in pharmacological studies, induces hippocampal neuronal cell injury under low tidal volume hypoxic conditions in guineapigs," J. Pharm. Pharmacol., 65, No. 1, 102-114 (2013).

2. N. P. Riksen, P. Smits, and G. A. Rongen, "The cardiovascular effects of methylxanthines," Handbook Exp. Pharmacol., 200, 413-437 ( 2011).

3. H. Uneyama, M. Munakata, and N. Akaike, "Caffeine response in pyramidal neurons freshly dissociated from rat hippocampus," Brain Res., 604, Nos. 1/2, 24-31 (1993).

4. C. C. Chou and T. W. Vickroy,"Antagonism of adenosine receptors by caffeine and caffeine metabolites in equine forebrain tissues," Am. J. Vet. Res., 64, No. 2, 216-224 (2003).

5. C. W. Hsu, C. S. Wang, and T. H. Chiu, "Caffeine and a selective adenosine A2A receptor antagonist induce sensitization and cross-sensitization behavior associated with increased striatal dopamine in mice," J. Biomed. Sci., 17, 4 (2010).

6. M. El Yacoubi, C. Ledent, M. Parmentier, et al., "In vivo labelling of the adenosine A2A receptor in mouse brain using the selective antagonist [3H]SCH 58261," Eur. J. Neurosci., 14, No. 9, 1567-1570 (2001).

7. O. Pauvert, C. Lugnier, T. Keravis, et al.,"Effect of sildenafil on cyclic nucleotide phosphodiesterase activity, vascular tone and calcium signaling in rat pulmonary artery," $B r . J$. Pharmacol., 139, No. 3, 513-522 (2003).

8. F. A. Belibi, D. P. Wallace, T. Yamaguchi, et al., "The effect of caffeine on renal epithelial cells from patients with autosomal dominant polycystic kidney disease," J. Am. Soc. Nephrol., 13, No. 11, 2723-2729 (2002).

9. D. Shi, W. L. Padgett, and J. W. Daly, "Caffeine analogs: effects on ryanodine-sensitive calcium-release channels and $\mathrm{GABA}_{\mathrm{A}}$ receptors," Cell. Mol. Neurobiol., 23, No. 3, 331-347 (2003).

10. S. S. Kang, K. S. Han, B. M. Ku, et al., " Caffeinemediated inhibition of calcium release channel inositol 1,4,5-trisphosphate receptor subtype 3 blocks glioblastoma invasion and extends survival," Cancer Res., 70, No. 3, 11731183 (2010).

11. C. Yang, S. Franciosi, and R. E. Brown, "Adenosine inhibits the excitatory synaptic inputs to basal forebrain cholinergic, GABAergic, and parvalbumin neurons in mice," Front. Neurol., 20, No. 4, 77 (2013).

12. J. A. Ribeiro and A. M. Sebastião, "Caffeine and adenosine," J. Alzheimer's Dis., 20, Suppl. 1, S3-S15 (2010).

13. Q. X. Chen, A. Stelzer, A. R. Kay, et al., "GABA receptor function is regulated by phosphorylation in acutely dissociated guinea-pig hippocampal neurones," J. Physiol., 420, 207-221 (1990).

14. M. Gyenes, Q. Wang, T. T. Gibbs, et al., "Phosphorylation factors control neurotransmitter and neuromodulator actions at the gamma-aminobutyric acid type A receptor," Mol. Pharmacol., 46, No. 3, 542-549 (1994).

15. C. S. Huang, J. Y. Ma, W. Marszalec, et al., "Effects of the nootropic drug nefiracetam on the GABA receptor-channel complex in dorsal root ganglion neurons," Neuropharmacology, 35, Nos. 9/10, 1251-1261 (1996).

16. N. M. Porter, R. E. Twyman, M. D. Uhler, et al., "Cyclic AMPdependent protein kinase decreases $\mathrm{GABA}_{\mathrm{A}}$ receptor current in mouse spinal neurons," Neuron, 5, No. 6, 789-796 (1990).

17. N. Gonçalves, A. T. Simões, R. A. Cunha, et al., "Caffeine and adenosine $\mathrm{A}(2 \mathrm{~A})$ receptor inactivation decrease striatal neuropathology in a lentiviral-based model of Machado-Joseph disease," Ann. Neurol., 73, No. 5, 655-666 (2013).

18. N. Vanattou-Saïfoudine, B. Behan, and A. Harkin, "Dopamine D1 receptor-mediated intracellular responses in the hypothalamus after co-administration of caffeine with MDMA," Basic Clin. Pharmacol. Toxicol., 110, No. 3, 283289 (2012) .

19. K. M. Capiotti, F. P. Menezes, L. R. Nazario, et al., " Early exposure to caffeine affects gene expression of adenosine receptors, DARPP-32 and BDNF without affecting sensibility and morphology of developing zebrafish (Danio rerio)," Neurotoxicol. Teratol., 33 No. 6, 680-685 (2011).

20. S. Sharmin, H. Guan, A. S. Williams, et al., "Caffeine reduces $11 \beta$-hydroxysteroid dehydrogenase type 2 expression in human trophoblast cells through the adenosine A(2B) receptor," PLoS One, No. 6, e3808 (2012).

21. R. L. Weir and R. E. Hruska," Interaction between methylxanthines and the benzodiazepine receptor," Arch. Int. Pharmacodyn. Ther, 265, No. 1, 42-48 (1983).

22. F. R. da Silva, R. Lazzarini, L. C. de Sá-Rocha, et al., "Effects of acute and long-term diazepam administrations on neutrophil activity: a flow cytometric study," Eur. J. Pharmacol., 478, Nos. 2/3, 97-104 (2003).

23. H. Z. Hu and Z. W. Li, "Modulation by adenosine of GABAactivated current in rat dorsal root ganglion neurons," $J$. Physiol., 501, 67-75 (1997).

24. M. Inoue, Y. Oomura, T. Yakushiji, et al., "Intracellular calcium ions decrease the affinity of the GABA receptor," Nature, 324, No. 6093, 156-158 (1986).

25. Y. C. Yu, L. H. Cao, X. L. Yang, et al.,“ Modulation by brain natriuretic peptide of GABA receptors on rat retinal ON-type bipolar cells," J. Neurosci., 26, No. 2, 696-707 (2006). 